\section{A review on the accumulation of heavy metals in coastal sediment of Peninsular Malaysia}

Accumulation of heavy metals in coastal sediment

Kamaruzzaman Yunus

International Islamic University Malaysia, Kuala Lumpur, Malaysia

M.A. Zuraidah

Kulliyyah of Science, International Islamic University Malaysia, Kuantan, Malaysia, and

Akbar John

Institute of Oceanography and Maritime Studies (INOCEM), Kulliyyah of Science, International Islamic University Malaysia, Kuantan, Malaysia

\begin{abstract}
Purpose - This study aims to examine the metal pollution in coastal sediment in the Peninsular Malaysia.

Design/methodology/approach - Approximately 141 published studies were screened from 1,285 documents and reviewed to determine the existing pollution status in the coastal areas of Peninsular Malaysia and the metals under review were $\mathrm{Pb}, \mathrm{Hg}, \mathrm{Cd}, \mathrm{Ar}, \mathrm{Cu}, \mathrm{Zn}, \mathrm{Cr}$ and $\mathrm{Ni}$. Sources of pollutants and their effect on biological systems, marine organisms and human health were addressed in this review as well as recommendation of heavy metal removal or remedies in short. Emphasis is placed on marine pollution, particularly on the toxic metal accumulation in biota.

Findings - This study has revealed the different concentrations of pollutants, low, moderately, and chronically contaminated areas from heavy metals and the consequences to aquatic ecosystem and indirectly to human health, since an increasing in the coastal developments in Peninsular Malaysia.

Originality/value - This study has revealed the different concentrations of pollutants, low, moderately, and chronically contaminated areas from heavy metals and the consequences to aquatic ecosystem and indirectly to human health, since an increasing in the coastal developments in Peninsular Malaysia.
\end{abstract}

Keywords Metal toxicity, Coastal sediments, Biomonitoring, Enrichment factor

Paper type Research paper

\section{Introduction}

Heavy metal concentration in aquatic ecosystem is measured in three conditions; in water, sediment and living organisms. Normally, heavy metals exist in lowest concentration in water and reach considerable concentrations in sediments followed by bioaccumulation

(C) Kamaruzzaman Yunus, M.A. Zuraidah and Akbar John. Published in Ecofeminism and Climate Change. Published by Emerald Publishing Limited. This article is published under the Creative Commons Attribution (CC BY 4.0) licence. Anyone may reproduce, distribute, translate and create derivative works of this article (for both commercial and non-commercial purposes), subject to full attribution to the original publication and authors. The full terms of this licence may be seen at http:// creativecommons.org/licences/by/4.0/legalcode

The research work was sponsored under Research Postdoctoral grant scheme (RPDF 18-0040004) IIUM and Fundamental Research Grant Scheme (FRGS 19 - 0210-0629).
Received 30 December 2019 Revised 8March 2020 Accepted 10 March 2020 
EFCC 1,1

level in living organisms (Ebrahimpour and Mushrifah, 2008). It does not exist in soluble forms for long time in waters, but are existent as suspended colloids or fixed by organic and mineral substances. Water contamination by heavy metals is one of the main types of pollution that may stress the biotic community in aquatic ecosystems. Heavy metals have a particular significance in ecotoxicology including both essential and non-essential elements, as they are highly persistent and all have the potential to be toxic to living organisms. These elements become toxic if concentration reaches above certain threshold bio-available levels (Zulkifli et al., 2010).

Sediments are known as a mixture of several components of mineral species and represent the important sink for various pollutants in aquatic systems, including heavy metals, and also play a useful role in the assessment of heavy metal contamination. Heavy metals discharged into environment might directly affect the overlying water (Alkarkhi et al., 2009; Zulkifli et al., 2010). Contaminated sediments in rivers, lakes and coastal regions have the potential to carriage ecological and river sediments are a major carrier of heavy metals in an aquatic environment. Heavy metals are released from sediments into water bodies and, consequently, to living organisms depending on the speciation of metals and other factors such as sediment $\mathrm{pH}$ and organic matter. In general, they reveal different physical and chemical behaviour in terms of chemical interactions, mobility, biological availability and potential toxicity (Li et al., 2000). Heavy metals are not removed from water but are accumulated in sediments, which then enter the food chain; hence, affects the ecological system and directly risks the human health (Loska and Wiechula, 2003). They may distribute in sediments as exchange-, organic matter- or residual-bound species. Total amount of heavy metal concentrations in sediment is useful to detect any net change; however, it does not give any sign about the chemical form of metals in sediment (Otero et al., 2000; Pagnanelli et al., 2004). Concentrations of certain trace elements such as Cd, Cu, $\mathrm{Ni}, \mathrm{Pb}, \mathrm{Zn}$ and other metals are often elevated above background levels in sediments that have been affected by anthropogenic activities.

The anthropogenic activities and natural phenomena such as weathering of rocks and volcanic activities, plays a main role in heavy metal concentrations in sediments. In most situations, the major contribution of anthropogenic heavy metals in a coastal area is of native origin, such as from agriculture, industries and urban development as well as other human activities near rivers and estuaries (Yunus et al., 2011; Tanjung, 2013) . Recently, great development has occurred around Malaysia, especially Peninsular Malaysia as industrialization, urbanization, the advancement of agriculture and other activities related to the modern era are occurring rapidly, which have directly influenced the coastal ecosystems that contain aquatic resources, for example, fish, which are also used by humans (Kamaruzzaman and Ong, 2009). Heavy metal concentrations contained in the effluents pollute river water and contaminate fish, eventually creating significant health risks and economic costs for residents, including the polluters (Poon et al., 2016). When large quantities of pollutants are released, there may be an immediate impact as measured by large-scale sudden mortalities of aquatic organisms, e.g. fish kills resulting from contamination of waterways with agricultural pesticides (Austin, 1999). Coastal and marine ecosystems worldwide are continuously being threatened by pollution issues, such as eutrophication, toxic substances, heavy metals, acidification and siltation, resulting from human activities (Tavakoly Sany et al., 2013). Decline in ecosystem productivity, loss of biological diversity, alteration of habitats and contamination of aquatic biota are among the most important effects of these pollutants (Zeitoun et al., 2014). An estimated $80 \%$ of pollution load in coastal and marine environments originate from industrial, agricultural, urban/rural and other land-based activities (Tiquio et al., 2017). Direct or indirect discharge 
of effluents from agriculture, aquaculture, domestic, industries, mining, paper and pulp mills, waste water treatment plants and sewage sludge (Nugegoda and Kibria, 2016). It will be important to measure the concentration of pollutant, particularly, mercury released from cement factories and coal combustion, which is predicted to be high (Yoshimoto et al., 2016).

Department of Environment, Ministry of Natural Resources and Environment Malaysia stated in every annual report the activities that can be the sources of anthropogenic pollutants and potentially contaminate the coastal environment. Until recently, there were limited number of reports on the status of trace elements in the aquatic environment in Malaysia, particularly in relation to intertidal sediments (Zulkifli et al., 2010). Nevertheless, continuous long-term monitoring is needed to assess the toxic heavy metals in this river, as it could ultimately have effects on food for the fishes, which are consumed by anglers and communities around the Kuantan River (Hossen et al., 2015). The aim of this review is to summarize the distribution of heavy metals, to provide preliminary data on the environmental conditions and to evaluate the risks from heavy metal contamination to human health.

Ecological systems are containing aquatic resources of food chain; therefore, they can accumulate heavy metals from food, water and sediments. Then, fish is main component of the aquatic food chain, which is used by majority of humans. The content of toxic heavy metals in fish can counteract their beneficial effects, and several adverse effects of heavy metals to human health have been recognized for a long time (Austin, 1999; Obasohan et al., 2010). Therefore, maintaining good marine environmental quality is crucial for several socio-economic reasons. In Malaysia, most of the case studies were conducted to investigate the impacts of these human activities on water and fish resources, as well as on human wellbeing from an ergonomics perspective. The objective of study is to help provide useful perceptions into sustainable relationships between humans and ecology in facilitating human well-being in consideration of the overall performance of the social-ecological system. Therefore, many monitoring programs have been established to assess the quality of fish for human consumption and to monitor the health of the aquatic ecosystem (Meche et al., 2010). In the past few decades, the concentrations of heavy metals in fish have been extensively studied in different parts of the world (Elnabris et al., 2013). Most of these studies concentrated mainly on the heavy metals in the fish muscles. However, other studies reported the distribution of metals in different organs such as the liver, kidneys, heart, gonads, bone, digestive tract and brain. According to the literatures, metal bioaccumulation by fish and subsequent distribution in organs is greatly inter-specific. In addition, many factors can influence metal uptake such as sex, age, size, reproductive cycle, swimming patterns, feeding behaviour and living environment, for example, geographical location (Ye et al., 2012).

This review article tries to determine the distribution and heavy metal concentration status in coastal sediment of Peninsular Malaysia. Sources of heavy metal $(\mathrm{Pb}, \mathrm{Hg}, \mathrm{Cd}, \mathrm{Ar}$, $\mathrm{Cu}, \mathrm{Zn}, \mathrm{Cr}$ and $\mathrm{Ni}$ ) pollution into coastal areas were examined and effects on human health were also assessed in this study in short. This review also aims to address the most useful tool as heavy metal removal to reducing the concentration of pollution to coastal sediment. An overall to explore method in minimizing the heavy metal pollutant in coastal sediment in Peninsular Malaysia indirectly minimized potential health risks for human.

\section{Methodology}

This review included a search of the online electronic databases SCOPUS, ProQuest, PubMed and Google Scholar. Each database was searched with multiple key words including sediments, Malaysian coastal area, Malaysian waters, metal toxicity,
Accumulation of heavy metals in coastal sediment 
EFCC 1,1

biomonitoring, enrichment factor and others. Relevant references from the bibliographies of identified papers were searched. Data of heavy metal concentration in sediment are also extracted from relevant articles and dissertations. These data are standardized in ppm unit. Data is summarized based on sampling location and metal concentration in sediments.

\subsection{Trace element of heavy metal}

Observation on heavy metal pollution in the aquatic ecosystem by using sediment has been conducted since years ago in Malaysia, as had been reported in the literature study (Ismail et al., 1993; Yap and Pang, 2011; Yap et al., 2003). However, these data are reported in the literature without comparing with distribution of metal by location and the toxicity level. Heavy metals, namely, $\mathrm{Pb}, \mathrm{Hg}, \mathrm{Cd}, \mathrm{As}, \mathrm{Cu}, \mathrm{Zn}, \mathrm{Cr}$ and $\mathrm{Ni}$ were discussed the sources of metal, biological mechanism and that the effect will indirectly impact human health upon consumption. Accumulation of substances or chemicals in a living organism or bioaccumulation can occur, especially in fishes. The levels of heavy metals varied significantly among fish species and organs (Mziray and Kimirei, 2016). Normally, muscles are not an active site for metal accumulation and always contain the lowest concentrations of all metals. Hence, the liver was the target organ for $\mathrm{Cu}, \mathrm{Zn}$ and Fe accumulation (Elnabris et al., 2013; El-Moselhy et al., 2014). However, in polluted aquatic habitats the concentration of metals in fish muscles may exceed the permissible limits for human consumption and indicate severe health threats (Rezaee Ebrahim Saraee et al., 2011). It is important to investigate heavy metal concentration and distribution in the environment because most heavy metals such as $\mathrm{Pb}, \mathrm{Hg}, \mathrm{Cd}$ and $\mathrm{As}$ are toxic and not biodegradable in nature thus, it will affect humans and ecosystem (Redzwan et al., 2014).

Table 1 presents the summarized distribution of heavy metal in Peninsular Malaysia for past 20 years. The summarized distribution can conclude that most heavy metal pollution to aquatic ecosystem focuses in western area, especially Selangor, which is the centre of industrial and development area.

\subsection{Plumbum}

Plumbum is highly toxic metal and a non-biodegradable hazardous heavy metal that easily accumulates on human body (Abbas et al., 2016). In human beings, it damages blood circulation, central nervous system, liver and kidneys (Kamaruzzaman and Ong, 2009). Hence, knowledge on $\mathrm{Pb}$ accumulation is highly essential for the usage of fishes for safer human consumption. Even though, the bioavailability of plumbum in marine environment is low, its constant bioaccumulation by aquatic organisms, especially fishes, would cause serious threats to human health when they are consumed.

The sources of contaminations of plumbum in the ecosystem are from paint, pesticides, smoking automobile emissions, burning of coal and mining (Abbas et al., 2016; Sia and Abdullah, 2012). Plumbum is used in many different ways, for example, it is used to produce batteries, ammunition, metal products such as solder and pipes and X-ray shielding devices, resulting in related health concerns; consequently, its usage has been drastically reduced in recent years. Similarly, the high concentration of lead at study area was situated at the boat stations where high boating activities take place and where the $\mathrm{pH}$ of the sediment was the lowest (Whitfield and Becker, 2014). While, drinking water major source of lead in human body cause containing substantial amount of lead which is initially it can enter the body through the digestive tract and lungs and carried spread by blood throughout the body. Presence of large quantity of lead in drinking water can cause anaemia, cancer, renal kidney disease, nervous system damage and mental retardation (Lim et al., 2013; Razak et al., 2015; Muhammad et al., 2012; Lim et al., 2012). 


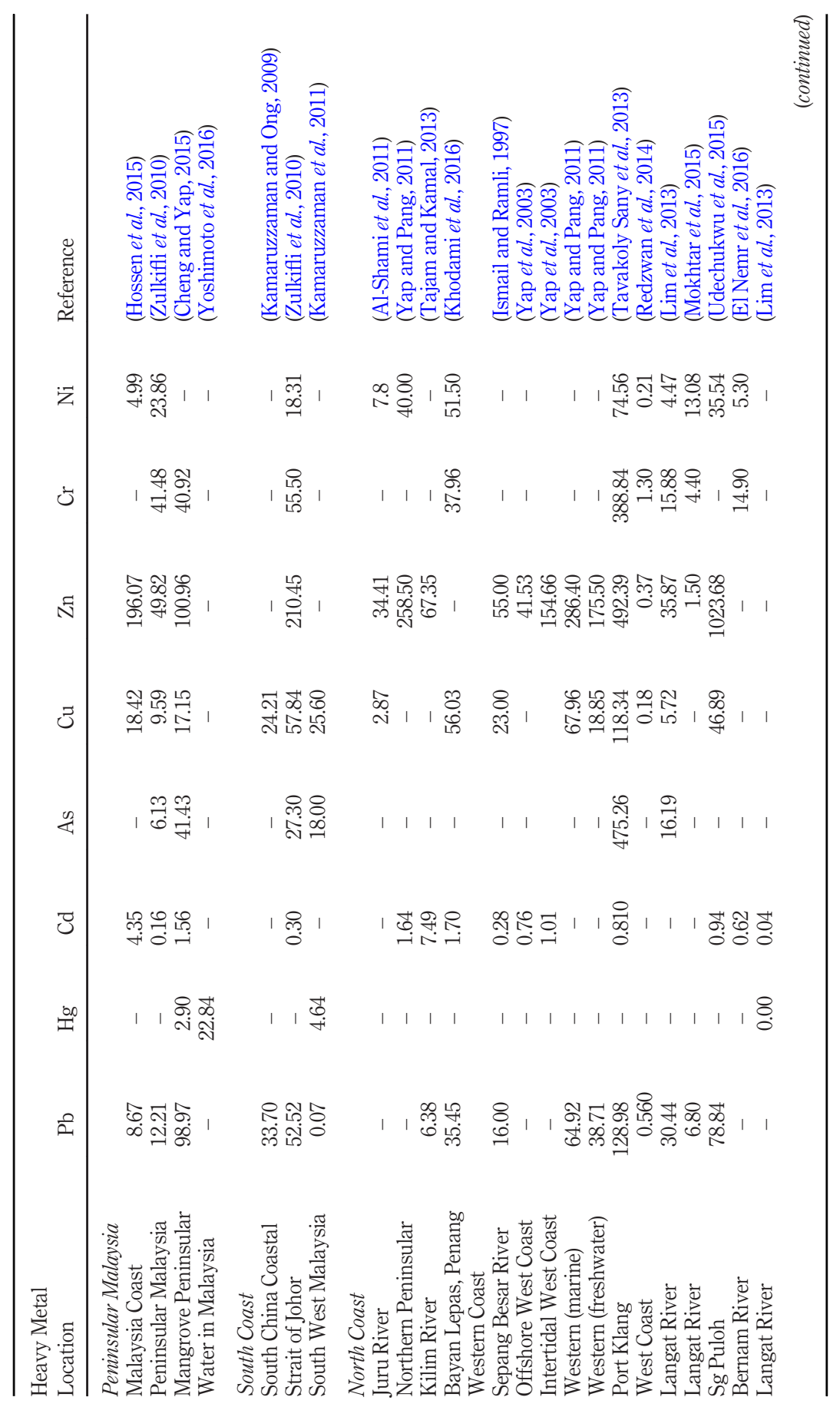

Accumulation of heavy metals in coastal sediment

25

Table 1.

Distribution of heavy metal (ppm dry weight) ( $\mathrm{Pb}, \mathrm{Hg}$, cd, $\mathrm{As}, \mathrm{Cu}, \mathrm{Zn}, \mathrm{Cr}$ and Ni) in Peninsular Malaysia coastal 
EFCC

1,1

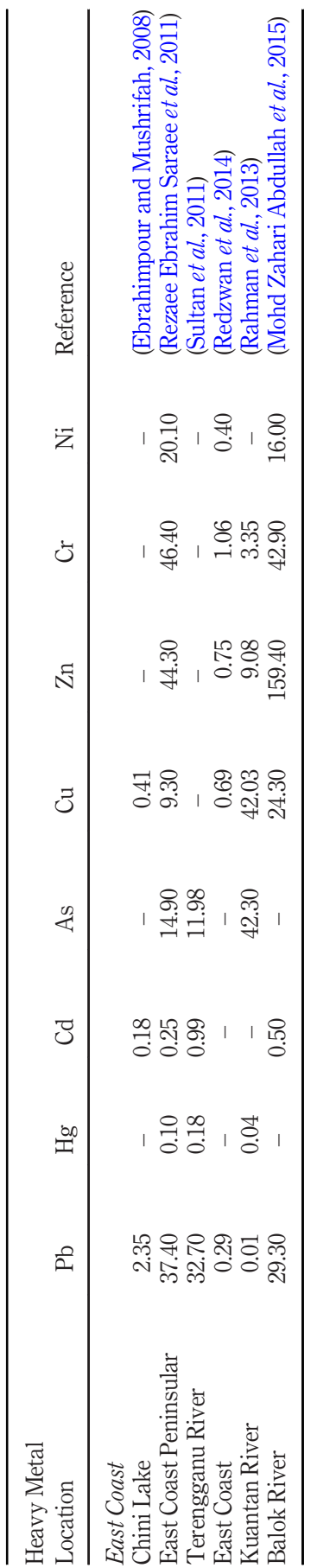

Table 1. 
EPA has determined that plumbum is a probable human carcinogen. It can affect every organ and system in the body. Long-term exposure in adults can result in decreased performance, in some tests that measure functions, of the nervous system; weakness in fingers, wrists or ankles; small increases in blood pressure; and anaemia. Regulatory limits by EPA is 15 parts per billion (ppb) in drinking water (Martin and Griswold, 2009). Refer to Table 1, for plumbum column; it clearly showed that almost all listed studies examined the amount of plumbum, as it one of the most toxic and high source of contamination to ecosystem. Most high concentration of plumbum is at western coast with highest amount $128 \mathrm{ppm}$ at Port Klang, which is known as the industrial area. This is considered a critical environmental issue for this region.

\subsection{Mercury}

Mercury, one of the heavy metal, is of special concern because it can result in many serious impacts on human health including the environment (Yoshimoto et al., 2016). Its toxicity and bioavailability is stated by its species, which in turn is influenced by natural, chemical and biological processes. It may change between different states and species in its cycle; however, its simplest form, elemental mercury, is harmful to humans and the environment (Issaro et al., 2010). After discharge of mercury from mineral deposits, fossil fuel or ores, the possible sites of its accumulation are bottom sediments, water bodies and earth's surface soils where it combines with other elements to form organic and inorganic mercury compounds. Metallic mercury is used to produce chlorine gas and caustic soda and is also used in thermometers, dental fillings, switches, light bulbs and batteries. Coal-burning power plants are the largest human-caused source of mercury emissions to the air in the USA. Mercury in soil and water is converted by microorganisms to methylmercury, a bioaccumulating toxin (Yoshimoto et al., 2016; Martin and Griswold, 2009).

Mercury is the element that will not degrade into harmless substances. It is highly mobile, cycling between earth surface and atmosphere, once it is liberated from ores. Although most mercury occurs in the inorganic form, methylmercury is the most toxic and readily bioaccumulated form of mercury. The major targets are the nervous system upon short-term exposure, whereas kidneys upon long-term exposure. The potential toxic effects of mercury include damage to kidneys, reproductive systems, immune, hematologic, cardiovascular, respiratory systems and brain (Aldroobi et al., 2013). The sources of mercury are mineral deposits, fossil fuel or ores, pesticides, batteries and paper industries. As Malaysia is one of the fast developing countries in Asia, it has experienced problems with regard to mercury pollution. Distribution of mercury has been summarized in Table 1 and shows high concentrations at a few locations of south and east coast area, which it is because of the industrial activities nearest to river as well as in seawater (Mokhtar et al., 2015).

However, the concentration of the total mercury decreased from pre-monsoon to postmonsoon because of heavy rainfall that increased levels of water, during this time, diluting and lowering the concentration of mercury and during pre-monsoon, the concentration of mercury was the highest (Rahman et al., 2013). This was because of industrial and residential activities, as mercury has been used in electrical appliances such as lamp and arc rectifiers. Improperly disposed household products, such as mercury-containing outdoor paints, can move through the soil and reach private well water supplies then enter the river water (Rahman et al., 2013). Regulatory limit of mercury concentration by EPA is $2 \mathrm{ppb}$ in drinking water and Food and Drug Administration (FDA) standardized 1 part of methylmercury in a million parts of seafood. Compared to mercury concentration in the Table 1, it was exceeding the permissible level of mercury; this situation is harmful to
Accumulation of heavy metals in coastal sediment 
EFCC 1,1

human and environment as well. The potential toxic effects of mercury include damage to kidneys, reproductive systems, immune, hematologic, cardiovascular, respiratory systems and brain (Bonsignore et al., 2013). Thus, more stringent regulatory controls have been imposed for mercury in many countries.

\subsection{Cadmium}

Cadmium is a very toxic metal and is a known human carcinogen. Severe damage to the lungs may occur through breathing high levels of cadmium. Ingesting very high levels severely irritates the stomach, leading to vomiting and diarrhoea. Long-term exposure to lower levels leads to a build-up in the kidneys and possible kidney disease, lung damage and fragile bones. Smokers get exposed to significantly higher cadmium levels than nonsmokers (Zulkifli et al., 2010; Perera et al., 2016). Many sources of cadmium are human activities and industries such as steel and plastic industries, cooling tower blow down, electroplating and metal plating, nickel-cadmium batteries, zinc of galvanized pipes, welding, fertilizers and nuclear emission plants. Entirely soils and rocks, including coal and mineral fertilizers, contain some cadmium from human activities and industries (Yoshimoto et al., 2016). Drinking water may be contaminated by cadmium, as a result of the presence of cadmium as an impurity in the zinc of galvanized pipes or cadmium-containing solders in fittings, water heaters, water coolers and taps (Damodharan, 2013). Cadmium concentrations in unpolluted natural waters are usually below $1 \mu \mathrm{g} / 1$ and it levels could be higher in areas supplied with soft water of low $\mathrm{pH}$, as this would tend to be more corrosive in plumbing systems containing cadmium. There was a higher fluctuation in the various sampling sites of river, which was attributed to the reason of the other industrial and anthropogenic sources. Upstream cadmium concentrations during all the four seasons were several times lesser than the cadmium concentration of raw effluent, which indicated the dilution effect of the river weather and also showed that this site is free from anthropogenic inputs and only the natural effects are the predominant factors in this particular site (Damodharan, 2013). Because of low pH, heavy metals may be desorbed from the sediment into water; thus, the highest concentrations of cadmium, copper and lead in water were found in lakes which had the lowest water $\mathrm{pH}$ and the lowest sediment $\mathrm{pH}$ (Ebrahimpour and Mushrifah, 2008). Cadmium concentrations in the lake water samples decreased with increasing $\mathrm{pH}$, because the metal binding abilities are decreased with decreasing $\mathrm{pH}$ because of proton binding. A decrease in $\mathrm{pH}$ will increase the competition between metals and hydrogen ions for binding sites and may dissolve metal complexes, releasing free metal ions into the water column (Rezaee Ebrahim Saraee et al., 2011). An increase in pH is generally accompanied by a decrease of the solubility of many toxic heavy metals in water (Udechukwu et al., 2015). Regulatory limits of cadmium based on EPA is 5 ppb or 0.005 ppm of cadmium in drinking water. According to FDA, permission of concentration in bottled drinking water should not exceed $0.005 \mathrm{ppm}(5 \mathrm{ppb})$. Meanwhile by OSHA, an average of 5 $\mathrm{mg} / \mathrm{m}^{3}$ of workplace air for an $8 \mathrm{~h}$ workday, $40 \mathrm{~h}$ workweek. Compared to concentration recorded in Table 1, most of the area was exceeding the maximum permitted level of cadmium concentration.

\subsection{Arsenic}

Arsenic is toxic and can cause numerous health effects in humans, including cancer. It is odourless and tasteless. Inorganic arsenic is a known carcinogen and can cause cancer of the skin, lungs, liver and bladder. Arsenic compounds are soluble in water, cannot be destroyed in the environment and can only change its form (El-Sorogy et al., 2016; Alamdar et al., 2017). Arsenic bioaccumulates in fish and shellfish. It present in the water originates from natural 
resources and human activity. It is released into the surface ground water by means of geological formation that happens in sedimentary rocks, geothermal water and from weathered volcanic rocks. Human activities such as mining, manufacturing, metallurgy, wood preservation and use of pesticides also introduce arsenic into the water bodies (Tanjung, 2013; Zeitoun et al., 2014; Freije, 2015). The reason that put concerns with arsenic in drinking water was that the majority of the population who had been exposed to arsenic in drinking water reported cases of cancer-based health concerns. High levels of arsenic contaminant have been found in Taiwan, India and West Bengal, where they have been exposed to much higher levels than the maximum possible concentration (Pagnanelli et al., 2004). These cases are only a correlation in the study, as the main mechanism of the toxicology levels of arsenic have not been studied thoroughly, but for sure both the individual and the population has been susceptible to the poisonous effects of arseniccontaminated water. The existence of arsenic in sediments affects bioaccumulation in fish, but accumulation of arsenic does not change according to the feeding habits of fish. Arsenic accumulation pattern in different organs of kidney, liver, gill and muscle, stresses that the water-borne pathway is more important for dietary pathways. Further, comprehensive assessment on the gills is necessary to understand the suitability of the species for biomonitoring studies (Perera et al., 2016). Table 1 presents the arsenic distribution in sediment of Peninsular Malaysia and the highest was at Port Klang area, which exceeds the permissible limit.

\subsection{Copper}

Copper has a number of applications in industrial and agricultural processes and it can be released into the environment from many sources such as mining, metal piping, chemical industries and pesticides industry. Though, our body needs some heavy metals such as copper and zinc, but in high concentration presence of these metals may cause hazardous effects (Abbas et al., 2016). Copper also plays a vital role in enzymatic processes and is essential for the synthesis of haemoglobin. However, very high intake will cause health problems. Drinking water can be a potential source for an intense copper exposition. Mercury is the most toxic metal and is followed by copper that is highly toxic for drinking water (Loska and Wiechuła, 2003; Gangaiya et al., 2001; Gismera et al., 2004). Besides, the example of effects of high intake of copper in human body are increased blood pressure and respiratory rates, damage in kidney and liver, convulsions, cramps, vomiting or even death (Abbas et al., 2016). Copper is also important for animal metabolism, however, the excessive ingestion of copper brings about serious threats, such as increased blood pressure and respiratory rates, damage in kidney and liver, convulsions, cramps, vomiting or even death (Mziray and Kimirei, 2016; Storelli et al., 2005; Taweel et al., 2013). Among the studied metals in fishes, copper was present highest concentration in the liver compared to gills and muscles. Permissible limit of copper concentration by US EPA is $1.3 \mathrm{mg} / \mathrm{L}$ and $2 \mathrm{mg} / \mathrm{L}$ by World Health Organization for drinking water. Table 1, in the summarized heavy metal distribution, shows most of the heavy metal pollution studies included examination of copper.

\subsection{Zinc}

Zinc plays a vital role in regulating many biochemical processes and physiological functions of living tissues. The presence of zinc in excess causes prominent health problems, for example, stomach nausea, skin irritations, cramps, vomiting and anaemia (Abbas et al., 2016). The human activities and industrial sources of zinc include brass platting, wood pulp production, ground and newsprint paper production, steel works with galvanizing lines and
Accumulation of heavy metals in coastal sediment 
EFCC 1,1

zinc and brass metal works. Waste concentrations of zinc ranges from less than 1 to more than $48,000 \mathrm{mg} \mathrm{L}^{-1}$ in various waste streams described in the literature. Zinc is released into environment from sediment entrainment, agricultural activities, groundwater intrusion or from a combination of these sources (Jan and Edward, 2016). The concentrations of $\mathrm{Cu}, \mathrm{Zn}$, $\mathrm{Mn}, \mathrm{Ni}, \mathrm{Cd}$ and $\mathrm{Pb}$ in the muscles of the analysed six fish species are presented, which shows that the highest concentrations were for zinc and the lowest were for lead and cadmium in fish muscles. There were vast differences among the heavy metal concentrations in the muscles of different fish species (Elnabris et al., 2013). Meanwhile, MFA permissible level of $\mathrm{Zn}$ for human consumption is $100 \mathrm{mg} / \mathrm{kg}$ wet weight and Table 1 shows zinc distribution area in Peninsular Malaysia sediment. The list of concentration of zinc is not exceeding the permissible limit for all studies recorded.

\subsection{Chromium}

Chromium is a metal found in natural deposits such as rocks (ores), animals, plants and soil and can be a liquid, solid or gas. Chromium is considered one of the earth crust's most abundant elements and it is estimated to be the sixth most abundant transition metal (Martin and Griswold, 2009). Chromium compounds bind to soil and are not likely to migrate to ground water, but they are very persistent in sediments in water. Its soluble forms are used in wood preservatives. Chromium is used in textile industries, electroplating, leather tanning, metal finishing and chromate preparation, protective coatings on metal (electroplating), magnetic tapes and pigments for paints, cement, paper, rubber, composition floor covering and other materials. Therefore, the potential source of chromium to drinking water contamination is industrial wastewater discharge to environment. .Chromium (VI) compounds are toxins and known human carcinogens, whereas chromium (III) is less toxic and an essential nutrient for human (Abbas et al., 2016; Martin and Griswold, 2009). In contrast, $\mathrm{Cr}(\mathrm{VI})$ is extremely toxic, found in various industrial waters and can cause severe diarrhoea, vomiting, pulmonary congestions and liver and kidney damage. Besides, breathing high levels can cause irritation to the lining of the nose, nose ulcers, runny nose and breathing problems, such as asthma, cough, shortness of breath or wheezing (Tanjung, 2013; Malkoc and Nuhoglu, 2007; Sarmani, 1989). Regulatory limit by EPA is 0.1 ppm in drinking water. Meanwhile, according to FDA limit should not exceed $1 \mathrm{mg} / 1$ (1 ppm) in bottled water. OSHA standardized an average between 0.0005 and $1.0 \mathrm{mg} / \mathrm{m}^{3}$ of workplace air for an 8-h workday and 40-h workweek, depending on the compound (Malkoc and Nuhoglu, 2007; Mokhtar et al., 2015; Oyetibo et al., 2016; Sarmani, 1989; Sfakianakis et al., 2015; Tanjung, 2013). Table 1 shows chromium distribution into sediment in Peninsular Malaysia. Obviously, summarized showed chromium studies most in heavy industrial at western coast Malaysia, which is area highest concentration of chromium contamination.

\subsection{Nickel}

Nickel is a non-biodegradable toxic heavy metal ion present in wastewater. The main source of nickel pollution in the water derives from a number of industrial production processes such as battery manufacturing, production of some alloys, zinc base casting, printing, electroplating and silver refineries (Li et al., 2000; Meche et al., 2010; Baldantoni et al., 2004). The toxic effects of nickel include dry cough, bone nose and lung cancer, cyanosis, rapid respiration, shortness of breath, tightness of the chest, chest pain and nausea. However, all fish species sampled from Galas River in Kelantan for nickel concentrations showed lower than the permissible levels recommended by the MFA and the FAO (Baharom and Ishak, 2015). Table 1 presents nickel distribution in sediment at Peninsular Malaysia, which shows the highest concentration was at Port Klang, $74.56 \mathrm{ppm}$. 


\section{Conclusion and recommendation}

The review has highlighted findings of heavy metal in sediment from studies carried out at Peninsular Malaysia coastal. Because of rapid industrialization and urbanization a negative impact has been affected on the positive health of the aquatic system. The contamination of water is also transmitted in the biological section, many of which are consumed as sustenance by humans, specifically local people. The present review is important not only from the aquatic animal health status and management point of view but also as it presents a comparative justification of heavy metals. Regulatory standards for discharges from human activities and industries that include process plants should be strictly controlled. Reprocessing or recycling of wastes containing heavy metals needs to be given greater emphasis for not only environmental and health considerations but also resource conservation measure. Monitoring of air, water and soil in the vicinity of the toxic metalprocessing units needs to be carried out more vigorously for the specific metal. Improved coordination among the relevant agencies could be effective for marine protected area management in Malaysia. In the future, it will be necessary to create reliable inventories for not only the atmosphere but also other media in Malaysia, by collecting more measurement data. In particular, it will be important to measure the concentration of heavy metal released from industries and factories, which are anticipated to be high. Further study on accumulation of pesticides and toxic metals in fish tissues should be undertaken because of usage of these chemicals in all over Malaysian coastal region. However, the levels of metals in fishes should be continuously monitored in potentially polluted areas, as fishes showed a tendency to accumulate heavy metal such as cadmium in muscles from polluted water.

\section{References}

Abbas, A., Al-Amer, A.M., Laoui, T., Al-Marri, M.J., Nasser, M.S., Khraisheh, M. and Atieh, M.A. (2016), "Heavy metal removal from aqueous solution by advanced carbon nanotubes: critical review of adsorption applications”, Sep Purif Technol. Elsevier B.V, Vol. 157, pp. 141-161.

Alamdar, A., Ali, S., Akber, M., Eqani, S., Hanif, N., Maria, S., et al. (2017), "Chemosphere human exposure to trace metals and arsenic via consumption of fish from river Chenab, Pakistan and associated health risks", Chemosphere, Vol. 168, pp. 1-9.

Aldroobi, K.S.A., Shukri, A., Bauk, S., Munem, E.M.A. and Abuarra, A. (2013), "Determination of arsenic and mercury level in scalp hair from a selected population in Penang, Malaysia using XRF technique", Radiation Physics and Chemistry, Vol. 91, pp. 9-14.

Alkarkhi, A.F.M., Ismail, N., Ahmed, A. and Easa, A.M. (2009), "Analysis of heavy metal concentrations in sediments of selected estuaries of Malaysia - a statistical assessment", Environmental Monitoring and Assessment, Vol. 153 No. 1-4, pp. 179-185.

Al-Shami, S.A., Che Salmah, M.R., Abu Hassan, A. and Siti Azizah, M.N. (2011), "Fluctuating asymmetry of Chironomus spp. (diptera: Chironomidae) larvae in association with water quality and metal pollution in Permatang Rawa River in the Juru river basin, Penang, Malaysia”, Water, Air, and Soil Pollution, Vol. 216 Nos 1/4, pp. 203-216.

Austin, B. (1999), "The effects of pollution on fish health", Journal of Applied Microbiology, Vol. 85 No. S1, pp. 234S-242S.

Baharom, Z.S. and Ishak, M.Y. (2015), "Determination of heavy metal accumulation in fish species in galas river, Kelantan and Beranang mining Pool, Selangor”, Procedia Environmental Sciences, Vol. 30, pp. 320-325.

Baldantoni, D., Alfani, A., Di Tommasi, P., Bartoli, G. and De Santo, A.V. (2004), “Assessment of macro and microelement accumulation capability of two aquatic plants", Environmental Pollution, Vol. 130 No. 2, pp. 149-156. 
EFCC 1,1

Bonsignore, M., Salvagio Manta, D., Oliveri, E., Sprovieri, M., Basilone, G., Bonanno, A., et al. (2013), "Mercury in fishes from Augusta Bay (Southern Italy): risk assessment and health implication", Food and Chemical Toxicology, Vol. 56, pp. 184-194.

Cheng, W.H. and Yap, C.K. (2015), "Potential human health risks from toxic metals via mangrove snail consumption and their ecological risk assessments in the habitat sediment from peninsular Malaysia", Chemosphere, Vol. 135, pp. 156-165.

Damodharan, U. (2013), Bioaccumulation of Heavy Metals in Contaminated River Water-Uppanar, Cuddalore, South East Coast of. Persepctive Water Pollut.

Ebrahimpour, M. and Mushrifah, I. (2008), "Heavy metal concentrations in water and sediments in Tasik Chini, a freshwater lake", Environmental Monitoring and Assessment, Vol. 141 No. 1-3, pp. 297-307.

El Nemr, A., El-Said, G.F., Ragab, S., Khaled, A. and El-Sikaily, A. (2016), "The distribution, contamination and risk assessment of heavy metals in sediment and shellfish from the Red Sea Coast, Egypt", Chemosphere, Vol. 165, pp. 369-380.

El-Moselhy, K.M., Othman, A.I., Abd El-Azem, H. and El-Metwally, M. (2014), "Bioaccumulation of heavy metals in some tissues of fish in the Red Sea", Egyptian Journal of Basic and Applied Sciences, Vol. 1 No. 2, pp. 97-105.

Elnabris, K.J., Muzyed, S.K. and El-Ashgar, N.M. (2013), "Heavy metal concentrations in some commercially important fishes and their contribution to heavy metals exposure in Palestinian people of Gaza Strip (Palestine)", Journal of the Association of Arab Universities for Basic and Applied Sciences, Vol. 13 No. 1, pp. 44-51.

El-Sorogy, A.S., Youssef, M., Al-Kahtany, K. and Al-Otaiby, N. (2016), "Assessment of arsenic in coastal sediments, seawaters and Molluscs in the Tarut island, Arabian Gulf, Saudi Arabia”, Journal of African Earth Sciences, Vol. 113, pp. 65-72.

Freije, A.M. (2015), "Heavy metal, trace element and petroleum hydrocarbon pollution in the Arabian Gulf: Review", Journal of the Association of Arab Universities for Basic and Applied Sciences, Vol. 17 No. 1, pp. 90-100.

Gangaiya, P., Tabudravu, J., South, R. and Sotheeswaran, S. (2001), "Heavy metal contamination of the Lami coastal environment”, The South Pacific Journal of Natural and Applied Sciences, Vol. 19 No. 1, pp. 24-29.

Gismera, M.J., Lacal, J., da Silva, P., Garcıä, R., Teresa Sevilla, M. and Procopio, J.R. (2004), "Study of metal fractionation in river sediments. A comparison between kinetic and sequential extraction procedures”, Environmental Pollution, Vol. 127 No. 2, pp. 175-182.

Hossen, M.F., Hamdan, S., Rahman, M.R., Hossen, M.F., Hamdan, S. and Rahman, M.R. (2015), "Review on the risk assessment of heavy metals in Malaysian clams", The Scientific World Journal, Vol. 2015, pp. 1-7.

Ismail, A., Badri, M.A. and Noor Ramlan, M. (1993), "The background levels of heavy metal concentration in sediments of the West Coast of Peninsular Malaysia”, Science of the Total Environment, Vol. 134, pp. 315-323.

Ismail, A. and Ramli, R. (1997), "Trace metals in sediments and molluscs from an estuary receiving pig farms effluent”, Environmental Technology, Vol. 18 No. 5, pp. 509-515.

Issaro, N., Besancon, S., Bermond, A. and, (2010), "Thermodynamic and kinetic study of the single extraction of mercury from soil using sodium-thiosulfate", Talanta, Vol. 82 No. 5, pp. 1659-1667.

Jan, S. and Edward, F.B. (2016), "Bioaccumulation and distribution of heavy metals (cd, $\mathrm{Cu}, \mathrm{Fe}, \mathrm{Ni}, \mathrm{Pb}$ and $\mathrm{Zn}$ ) in the different tissues of Chicoreus capucinus lamarck (mollusca: Muricidae) collected from Environment Asia”, Environ Asia, Vol. 3 No. 1, pp. 65-71.

Kamaruzzaman, B., Rina, Z., Akbar John, B. and Jalal, K. (2011), "Heavy metal accumulation in commercially important fishes of South West Malaysian Coast", Research Journal of Environmental Sciences, Vol. 5 No. 6, pp. 595-602. 
Kamaruzzaman, Y. and Ong, M.C. (2009), "Geochemical proxy of some chemical elements in sediments of Kemaman river estuary, Terengganu”, Malaysia. Sains Malaysiana, Vol. 38 No. 5, pp. 631-636.

Khodami, S., Surif, M., W.O, W.M. and Daryanabard, R. (2016), "Assessment of heavy metal pollution in surface sediments of the Bayan Lepas area, Penang, Malaysia”, Marine Pollution Bulletin, Vol. 114 No. 1, pp. 615-622.

Li, X., Shen, Z., Wai, O.W.H., Li, Y., Li, X. and Shen, Z. (2000), "Chemical partitioning of heavy metal contaminants in sediments of the pearl river estuary", Chemical Speciation and Bioavailability, Vol. 12 No. 1, pp. 17-25.

Lim, W.Y., Aris, A.Z. and Ismail, T. (2013), "Spatial geochemical distribution and sources of heavy metals in the sediment of Langat river", Environmental Forensics, Vol. 14 No. 2, pp. 133-145.

Lim, W.Y., Aris, A.Z. and Zakaria, M.P. (2012), "Spatial variability of metals in surface water and sediment in the Langat river and geochemical factors that influence their water-sediment interactions”, The Scientific World Journal, Vol. 2012, pp. 1-14.

Loska, K. and Wiechuła, D. (2003), "Application of principal component analysis for the estimation of source of heavy metal contamination in surface sediments from the Rybnik reservoir", Chemosphere, Vol. 51 No. 8, pp. 723-733.

Malkoc, E. and Nuhoglu, Y. (2007), "Potential of tea factory waste for chromium (VI) removal from aqueous solutions: Thermodynamic and kinetic studies", Separation and Purification Technology, Vol. 54 No. 3, pp. 291-298.

Martin, S., Griswold, W. (2009), "Human health effects of heavy metals", Cent Hazard Subst ..., pp. 1-6.

Meche, A., Martins, M.C., Lofrano, B., Hardaway, C.J., Merchant, M. and Verdade, L. (2010), "Determination of heavy metals by inductively coupled plasma-optical emission spectrometry in fish from the Piracicaba river in Southern Brazil", Microchemical Journal, Vol. 94 No. 2, pp. 171-174.

Mohd Zahari Abdullah, M., Abd Manap, N.R., Saat, A., Hamzah, Z. and Abas, M.T. (2015), "Evaluation of heavy metal contamination levels of Balok river sediments in Pahang, Malaysia based on geoaccumulation index and supported with enrichment factor", Malaysian J Anal Sci, Vol. 19 No. 4, pp. 707-714.

Mokhtar, N.F., Aris, A.Z. and Praveena, S.M. (2015), "Preliminary study of heavy metal (Zn, Pb, Cr, Ni) contaminations in Langat river estuary, Selangor", Procedia Environmental Sciences, Vol. 30, pp. 285-290.

Muhammad, B.G., Jaafar, M.S., Rahman, A.A. and Ingawa, F.A. (2012), "Determination of radioactive elements and heavy metals in sediments and soil from domestic water sources in Northern peninsular Malaysia”, Environmental Monitoring and Assessment, Vol. 184 No. 8, pp. 5043-5049.

Mziray, P. and Kimirei, I.A. (2016), "Bioaccumulation of heavy metals in marine fishes (Siganus sutor, Lethrinus harak, and Rastrelliger kanagurta) from Dar Es Salaam Tanzania”, Regional Studies in Marine Science, Vol. 7, pp. 72-80.

Nugegoda, D. and Kibria, G. (2016), Effects of Environmental Chemicals on Fish Thyroid Function: Implications for Fisheries and Aquaculture in Australia. Gen Comp Endocrinol, Elsevier Inc.

Obasohan, E.E., Agbonlahor, D.E. and Obano, E.E. (2010), "Water pollution: a review of microbial quality and health concerns of water, sediment and fish in the aquatic ecosystem", African J Biotechnol, Vol. 9 No. 4, pp. 423-427.

Otero, X.L., Huerta-Diaz, M.A. and Macõâas, F. (2000), "Heavy metal geochemistry of saltmarsh soils from the RõÂa of Ortigueira (ma ${ }^{\circledR} \mathrm{c}$ and Ultrama ${ }^{\circledR} \mathrm{c}$ areas”, Environmental Pollution, Vol. 110 No. 2, pp. 285-296.

Oyetibo, G.O., Miyauchi, K., Huang, Y., Chien, M.F., Ilori, M.O., Amund, O.O. and Endo, G. (2016), "Biotechnological remedies for the estuarine environment polluted with heavy metals and persistent organic pollutants", International Biodeterioration and Biodegradation, Vol. 119, pp. 614-625. 
EFCC 1,1

Pagnanelli, F., Moscardini, E., Giuliano, V. and Toro, L. (2004), "Sequential extraction of heavy metals in river sediments of an abandoned pyrite mining area: pollution detection and affinity series", Environmental Pollution, Vol. 132 No. 2, pp. 189-201.

Perera, P.C.T., Sundarabarathy, T.V., Sivananthawerl, T., Kodithuwakku, S.P. and Edirisinghe, U. (2016), "Arsenic and cadmium contamination in water, sediments and fish is a consequence of paddy cultivation: evidence of river pollution in Sri Lanka", Achievements in the Life Sciences, Vol. 10 No. 2, pp. 144-160.

Poon, W.C., Herath, G., Sarker, A., Masuda, T. and Kada, R. (2016), "River and fish pollution in Malaysia: a green ergonomics perspective”, Applied Ergonomics, Vol. 57, pp. 80-93.

Rahman, M.M., Awang, M.B., Jalal, K.A., Aisha, S. and Kamaruzzaman, B.Y. (2013), "Study on toxic chemicals in Kuantan river during pre and post monsoon season", Aust J Basic Appl Sci, Vol. 7 No. 4, pp. 24-30.

Razak, N.H., Praveena, S.M., Aris, A.Z. and Hashim, Z. (2015), "Drinking water studies: a review on heavy metal, application of biomarker and health risk assessment (a special focus in Malaysia)", Journal of Epidemiology and Global Health, Vol. 5 No. 4, pp. 297-310. Saudi Arabia;

Redzwan, G., Abdul Halim, H., Alias, S.A. and Rahman, M.M. (2014), "Assessment of heavy metal contamination at west and east coastal area of peninsular Malaysia", Malaysian Journal of Science, Vol. 33 No. 1, pp. 23-31.

Rezaee Ebrahim Saraee, K., Abdi, M.R., Naghavi, K., Saion, E., Shafaei, M.A. and Soltani, N. (2011), "Distribution of heavy metals in surface sediments from the South China sea ecosystem, Malaysia”, Environmental Monitoring and Assessment, Vol. 183 No. 1-4, pp. 545-554.

Sarmani, S. (1989), "The determination of heavy metals in water, suspended materials and sediment from Langat river", Hydrobiologia, Vol. 176-177 No. 1, pp. 233-238.

Sfakianakis, D.G., Renieri, E., Kentouri, M. and Tsatsakis, A.M. (2015), "Effect of heavy metals on fish larvae deformities: a review", Environmental Research, Vol. 137, pp. 246-255.

Sia, S.G. and Abdullah, W.H. (2012), "Enrichment of arsenic, lead, and antimony in Balingian coal from Sarawak, Malaysia: modes of occurrence, origin, and partitioning behaviour during coal combustion", International Journal of Coal Geology, Vol. 101, pp. 1-15.

Storelli, M.M., Storelli, A., D’Addabbo, R., Marano, C., Bruno, R. and Marcotrigiano, G.O. (2005), “Trace elements in loggerhead turtles (Caretta Caretta) from the Eastern Mediterranean sea: overview and evaluation”, Environmental Pollution, Vol. 135 No. 1, pp. 163-170.

Sultan, K., Shazili, N.A. and Peiffer, S. (2011), "Distribution of Pb, As, Cd, Sn and Hg in soil, sediment and surface water of the tropical river watershed, Terengganu (Malaysia)", Journal of HydroEnvironment Research, Vol. 5 No. 3, pp. 169-176.

Tajam, J. and Kamal, M.L. (2013), "Marine environmental risk assessment of Sungai Kilim, Langkawi, Malaysia: heavy metal enrichment factors in sediments as assessment indexes", International Journal of Oceanography, Vol. 2013, pp. 1-6.

Tanjung, E.L. (2013), Assessment of Heavy Metal Deposition in Surface Water and Sediment in Balok and Tunggak River, Kuantan.

Tavakoly Sany, S.B., Salleh, A., Rezayi, M., Saadati, N., Narimany, L. and Tehrani, G.M. (2013), "Distribution and contamination of heavy metal in the coastal sediments of port Klang, Selangor, Malaysia”, Water, Air, and Soil Pollution, Vol. 224 No. 4.

Taweel, A., Shuhaimi-Othman, M. and Ahmad, A.K. (2013), "Assessment of heavy metals in tilapia fish (Oreochromis niloticus) from the Langat river and engineering lake in Bangi, Malaysia, and evaluation of the health risk from tilapia consumption", Ecotoxicology and Environmental Safety, Vol. 93, pp. 45-51.

Tiquio, M., Marmier, N. and Francour, P. (2017), "Management frameworks for coastal and marine pollution in the European and South East Asian regions", Ocean and Coastal Management, Vol. 135, pp. 65-78. 
Udechukwu, B.E., Ismail, A., Zulkifli, S.Z. and Omar, H. (2015), "Distribution, mobility, and pollution assessment of $\mathrm{Cd}, \mathrm{Cu}, \mathrm{Ni}, \mathrm{Pb}, \mathrm{Zn}$, and $\mathrm{Fe}$ in intertidal surface sediments of $\mathrm{Sg}$. Puloh mangrove estuary, Malaysia", Environmental Science and Pollution Research, Vol. 22 No. 6, pp. 4242-4255.

Whitfield, A.K. and Becker, A. (2014), "Impacts of recreational motorboats on fishes: a review", Marine Pollution Bulletin, Vol. 83 No. 1, pp. 24-31.

Yap, C.K. and Pang, B.H. (2011), "Anthropogenic concentrations of cd, $\mathrm{Ni}$ and $\mathrm{Zn}$ in the intertidal, river and drainage sediments collected from North Western peninsular Malaysia”, Pertanika J Sci Technol, Vol. 19 No. 1, pp. 93-107.

Accumulation of heavy metals in coastal sediment

Yap, C.K. and Pang, B.H. (2011), “Assessment of $\mathrm{Cu}, \mathrm{Pb}$, and $\mathrm{Zn}$ contamination in sediment of North Western peninsular Malaysia by using sediment quality values and different geochemical indices", Environmental Monitoring and Assessment, Vol. 183 No. 1-4, pp. 23-39.

Yap, C.K., Ismail, A. and Tan, S.G. (2003), "Cd and Zn concentrations in the straits of Malacca and intertidal sediments of the West Coast of peninsular Malaysia”, Mar Pollut Bull, Vol. 46 No. 10, pp. 1348-1353.

Ye, H., Jin, Y., Lin, S., Liu, M., Yang, Y., Zhang, M., et al. (2012), "Effect of pulsed electric fields on the activity of neutral trehalase from beer yeast and RSM analysis", International Journal of Biological Macromolecules, Vol. 50 No. 5, pp. 1315-1321.

Yoshimoto, N., Takaoka, M., Fujimori, T., Oshita, K., Sakai, N. and Kdir, S.A.S.A. (2016), "Substance flow analysis of mercury in Malaysia”, Atmos Pollut Res, Vol. 7 No. 5, pp. 799-807.

Yunus, K., Yusuf, N.M., Shazili, N.A.M., Chuan, O.M. and Saad, S. (2011), "Heavy metal concentration in the surface sediment of Tanjung Lumpur", Sains Malasiana, Vol. 40 No. 2, pp. 89-92.

Zeitoun, M.M., Sayed, E. and Mehana, E. (2014), "Impact of water pollution with heavy metals on fish health: overview and updates", Glob Vet, Vol. 12 No. 2, pp. 219-231.

Zulkifli, S.Z., Ismail, A., Mohamat-Yusuff, F., Arai, T. and Miyazaki, N. (2010), "Johor strait as a hotspot for trace elements contamination in Peninsular Malaysia", Bulletin of Environmental Contamination and Toxicology, Vol. 84 No. 5, pp. 568-573.

Zulkifli, S.Z., Mohamat-Yusuff, F., Arai, T., Ismail, A. and Miyazaki, N. (2010), “An assessment of selected trace elements in intertidal surface sediments collected from the Peninsular Malaysia", Environmental Monitoring and Assessment, Vol. 169 Nos 1/4, pp. 457-472.

\section{Further reading}

Kamaruzzaman, Y., Ong, M.C., Shahbudin, S. and Nor, O.M. (2009), "Accumulation of lead and copper in Rhizophora apiculata from Setiu mangrove Forest, Terengganu”, J Environ Biol, Vol. 30 No. 5 Suppl, pp. 821-824.

\section{Corresponding author}

Kamaruzzaman Yunus can be contacted at:kama@iium.edu.my

For instructions on how to order reprints of this article, please visit our website: 